\title{
CONFLICTS BETWEEN FARMERS AND CONSERVATIONISTS: THE ROLE OF COMMUNICATION IN THE MANAGEMENT OF NATURAL RESOURCES
}

\author{
TAMARA MEIEROVÁ \\ Department of Environmental Studies, Faculty of Social Sciences, Masaryk University. \\ Jostova 10, 60200, Brno, Czech Republic, e-mail: faberova.tamara@gmail.com
}

Received: $18^{\text {th }}$ Nowember 2019, Accepted: $4^{\text {th }}$ August 2020

\begin{abstract}
The importance of communication in conflict situations between conservationists and farmers about problems related to agricultural practices such as erosion, biodiversity loss, and water quality has been highlighted frequently. However, in the Czech Republic, there is a very limited amount of scientific data about this issue. This article presents a literature review summarising evidence on how conflicts between farmers and environmentalists proceed; steps that can be taken to achieve progress in face-to-face communication and there is also a case study of a specific collaborative partnership from a small parish in South Moravia that focuses on improving natural values. Recommendations on how to build more constructive dialogue and develop cooperation between various groups are analysed, and principles that enhance dialogue and may contribute to overcoming disagreements through partnership are indicated. The collaborative partnership in the case study involves a farmer working together with a municipality and other stakeholders on a local level to improve nature conservation and ecosystem services. The majority of the general principles of collaboration and communication for conflict resolution that were identified in the literature review were fulfilled; nevertheless, the partnership currently has limited outreach as the two agribusiness companies which manage the majority of the land in the parish have not been included.
\end{abstract}

Keywords: nature conservation communication, conflicts between farmers and environmentalists, collaborative natural resource management, collaborative partnership

\section{INTRODUCTION}

The importance of nature conservation communication (NC communication) and dialogue to bringing progress to conflicts between groups with different nature conservation interests in order to improve natural values has been emphasised by professional conservationists and nature managers alike (Rientjes, 2000; Bonar, 2007; Van Bommel et al., 2009; Cox \& Pezzullo, 2016). However, until now little research has been carried out on the role of communication between Czech farmers and environmentalists regarding the impacts of agricultural activities on the landscape such as soil compaction and desiccation, erosion, local flooding, and the decline of biodiversity.

Belonging to occupational groups with different characteristics, farmers and conservationists frequently have only very scant interaction in their typical working lives, 
Meierová T.: Conflicts between farmers and conservationists: the role of communication in the management of natural resources

which does not contribute to conservationists and farmers meeting and talking to each other regularly (Rientjes, 2000). Farmers and conservationists use terms and phrases that the other group may not fully understand or one group may understand their meaning differently from the other group, such as nature, biodiversity, ecosystem services, agro-technical practices, and other terms (Rientjes, 2000; Bonar, 2007). Communication is also hampered by the prejudices that groups have about each other (Ingram et al., 2016; Ramisch, 2014). The media presentation of groups often does not contribute to reducing these prejudices between farmers and environmentalists (Peterson et al., 2016). In the Czech media, farmers, especially large enterprises, are often considered a group that lives on subsidies and destroys the environment for financial gain (Bednárová, 2016; Hanák, 2017). On the other hand, people promoting nature conservation, whether from the state administration, expert workplaces and universities, or NGOs, are often described in informal interviews by farmers as obstacles limiting progress and the routine work of farmers. Similar arguments are used regularly by farmers from other countries (Bonar, 2007; Rientjes, 2000; Peterson et al., 2016).

A local example from Sweden by Peterson et al. (2016) can be used to illustrate a typical environmental conflict between farmers and conservationists. For several years farmers in the Kalmar region in the southern Sweden, were in conflict with the government and conservationists regarding the use of floodplains around the River Emån. The farmers demanded that the river be regulated because of crop damage during the regular floods, while conservationists emphasised the adverse effects of such regulation on biodiversity and the fact that farmers in the area had produced crops so far regardless of the presence of floods. The dispute went on for years. Peterson et al. (2016) pointed out the key role played by communication between the conservationists and farmers in the development of the conflict, especially its long-term course and dynamics: the priorities and goals were not communicated between the groups and therefore were not transparent. The lack of understanding between the parties created conditions that step by step increased the distrust between the groups, which subsequently contributed to the negative atmosphere during the following discussions. The conflict escalated and contributed to an increasingly negative impression of the conservationists in the eyes of the farmers and also vice versa, which, according to Peterson et al. (2016), characterises negative communication dynamics. Many other conflicts between farmers and environmentalists have been documented by other scientists, highlighting the role communication plays in the process (Depoe, 2011; Leeuwis, 2000; Henle et al., 2008; McEachern, 1992; Kächele \& Dabbert, 2002; Ravnborg \& Westernman, 2002), whereas a significant number of cases had the character of long-term conflicts. If the communication efforts are successful, the parties may perceive the potential that exists for tackling the environmental problem together and the advantages of doing so the problem and conflict can provide a basis for collaborative efforts and partnerships (Rientjes, 2000).

In the Czech Republic, conflicts between environmentalists and farmers regarding natural resources are mentioned very rarely and are not closely described (Daňková, 2009; Štěpán, 2017; Śálek et al., 2018) but appear more frequently in the media, which highlight the deterioration of natural resources as a result of agricultural practices (e.g. Cibulka, 2018; Bednárová, 2016; Hanák, 2017). The data of Šálek et al. shows a significant difference between Northern Austria and South Moravia in the Czech Republic in terms of agricultural usage and its implications for biodiversity. In Austria, more non-cropped elements and smaller fields were present and were accompanied by more abundant populations of insects and birds. There is clear evidence for a positive correlation between the number of landscape features and the abundance of spiders, butterflies, and, on a larger scale, also birds. However, 
efforts to re-establish the non-cropped elements in the agricultural landscape that are desirable for conservationists represent a rather tricky task, also because of the fact that the majority of agricultural land is managed by larger agricultural businesses that seem unresponsive to the requests of conservationists (Faberová, 2016; Cibulka, 2018).

\section{Content of the article}

The focus of this article is primarily direct person-to-person communication as a tool to solve conflicts about environmental issues (Klocker, 2015:13). Person-to-person communication as used in this article comprises discussions and dialogues of varying lengths between conservationists and farmers regarding the usage of natural resources and the agricultural practices that affect them. Person-to-person or face-to-face communication is characterised by the presence of two or more people at the same site, who can interactively exchange information and know-how, which is sometimes contradictory (Klöckner, 2015:14). If constructive, the communication process can build trust and the relationship between the parties or, if unsatisfactory, harm them (Peterson et al., 2016; Rientjes, 2000). The article does not focus primarily on indirect environmental communication, which, according to both Klockner (2015:14) and Cox \& Pezzullo (2016), includes other communication channels such as printed materials, communication by telephone, videos, media campaigns, and media broadcasts about environmental issues related to agriculture.

First, a literature review about communication as a tool to solve conflict situations between environmentalists and farmers is presented. Also included are what are called collaborative natural resources management or collaborative partnerships ${ }^{1}$, which aim, despite the differences between the goals of the participants, to create cooperation, mediate and reduce conflict and may contribute to an understanding of how long-term constructive dialogue can bring benefits not only for the environment but also the participants in the partnership. Second, a case study of a partially hidden conflict concerning natural resource management involving a small farmer who is, at the same time, a conservationist, a small municipality, and a larger agribusiness is described. The analytical framework drawn from the literature review was used for the analysis.

\section{METHODS}

The literature review was carried out using both scientific journals and monographs as sources of information. Literature was collected before the work on the case study in the spring of 2018 and 2019 through the EBSCOhost, Google Scholar, and Web of Knowledge databases, but also a general internet search, which was especially useful for monographs about conflicts and their impacts written by professional conservationists, as well as reports issued by governments, such as Dwyer et al. (2007). The keywords that were used were conflicts between farmers and conservationists, collaborative partnerships, and subsequently collaborative natural resource management. Geographically, the focus of the review was on studies from Europe and the US. In total, over 60 sources comprising studies, reports, and monographs were examined; however, analyses of conflicts between conservationists, foresters, and wood-processing industries prevailed, and conflicts related to farming

\footnotetext{
${ }^{1}$ According to Conley \& Moote (2003), more than five different terms have been used by various authors to describe partnerships working for better management of natural resources, including collaborative natural resources management. In this article, the shorter 'collaborative partnership' is used in most cases, as for instance, in Bidwell \& Ryan (2006) and Saltiel (1998).
} 
Meierová T.: Conflicts between farmers and conservationists: the role of communication in the management of natural resources

represented a minority. Only materials describing conflict cases concerning farmers were included in the review.

The analytical framework for the case study (Fig. 1) consisted of a pre-interview stage in which a semi-structured interview was designed according to grounded theory principles (Straus \& Corbin, 1999), the farmer for the case study was selected, and the findings from the literature review were processed into preliminary principles of collaborative partnerships. Next, the interview stage took place and was followed by transcribing the interview, initial analysis with open coding, and general assessment of how the principles of collaborative partnerships are fulfilled. Finally, in the analytical stage, a second interview with the farmer took place, axial and selective coding according to grounded theory was performed, and analysis of the data according to grounded theory and the principles of collaboration was carried out. Therefore, in total there were two in-depth semi-structured interviews with the farmer, a field visit, and study of additional materials about the area of interest, which consisted of a landscape territorial study (Ekotoxa, 2018) and the web pages of the municipality, the farmer, and two bigger farms in the $\operatorname{area}^{2}$. The interviews with the small farmer were undertaken in the autumn of 2019. The first one lasted for 2.5 hours and was followed by an hour-long field trip to his plots, an additional one-hour telephone interview to gain a deeper understanding of the communication process, the initiation of collaboration, and development after the initial analysis of the case study was produced. The interview design was created according to the methods described in the grounded theory approach as developed in Strauss \& Corbin (1999). Grounded theory (GT) is one of the most frequently used methods in the social sciences; it does not focus on testing a hypothesis but on how the research problem is manifested in reality (Strauss \& Corbin, 1999: 14). GT influenced the further perspective on the case study as it suggests including in the research reflections on the story of the farmer, his professional development and willingness to protect nature, and the importance of contextual factors affecting the establishment and maintenance of cooperation.

The interview was a part of a larger dissertation research study during which, in total, 21 farmers were interviewed about their motivations to protect natural resources. The rationale for selecting this particular farmer was the following: as no data about any Czech collaborative partnership between farmers, a municipality, and conservationists or other groups were found in the literature, I looked for an example of collaboration among farmers, environmentalists, and municipalities in South Moravia. Only one particular farmer, who was at the same time an environmentalist, was involved in the form of a collaborative partnership with the municipality and other stakeholders from the local village such as owners of plots in the parish who are concerned about the state of their local environment and want to actively participate in creating a healthier countryside. At the same time, clear disagreements between the opinions and plans concerning landscape management of smaller farmers and larger agricultural businesses in the area were present, leading to a partially hidden conflict related to their views on how the surrounding arable landscape should be managed, the conflicting agricultural and conservation practices that are employed, and also the practical steps they take to alter the land use to suit their goals. The small farmer was approached to analyse how the conflict was addressed and the reasons why the collaboration was initiated and developed and also its future perspectives.

\footnotetext{
${ }^{2}$ The web pages are not listed as they would disclose the identity of the farmers and location of the municipality.
} 
Fig. 1: Analytical framework for the case study

\begin{tabular}{|l|l}
\hline \multicolumn{2}{|l}{ Analytical framework for the case study } \\
\hline \multirow{3}{*}{ 1. Pre-interview stage } & interview design developed according to the grounded theory \\
\cline { 2 - 2 } & farmer involved in a partnership found and contacted \\
\cline { 2 - 2 } & principles of collaborative partnerships according to the literature review assessed \\
\hline \multirow{3}{*}{ 2. Interview stage } & interview with the farmer, field visit \\
\cline { 2 - 2 } & interview transcribed \\
\cline { 2 - 2 } & preliminary analysis of the data - open coding \\
\cline { 2 - 2 } & webpages of the farmer and municipality analysed \\
\hline \multirow{3}{*}{ 3. Analytical stage } & second interview carried out \\
\cline { 2 - 2 } & next stage data analysis - axilar and selective coding \\
\cline { 2 - 2 } & revision of the collaborative partnership principles \\
\cline { 2 - 2 } & final analysis of data according to grounded theory and principles of collaboration \\
\hline
\end{tabular}

The key findings from the literature review indicating how conflicts between farmers and environmentalists may be approached were synthesised into principles of collaboration, which were used during the analysis. They include the five principles of collaborative partnerships of Cox \& Pezzullo (2016) and Pezzullo \& Cox (2018) but also other eight principles highlighted by other authors that I found relevant for Czech conditions, which are described in the Results section and are summarised at the end of the literature review.

\section{RESULTS}

\section{Literature review}

Research focusing primarily on nature conservation communication (NC communication), specifically between farmers and environmentalists, was rather scarce until the 2000s; more publications have appeared in the last two decades. Several monographs on NC communication that present options for promoting general pro-environmental behaviour ${ }^{3}$ or factors contributing to such behaviour are available (Cox \& Pezzullo, 2016; Peterson et al., 2016; Depoe et al., 2011; Klöckner, 2015; Jacobson, 2009). Nevertheless, only a few studies focused on communication with farmers with the primary goal of contributing to a change in farmers' behaviour (Dwyer et al., 2007; Rientjes, 2000). More research focused on topics that include an aspect of NC communication: collaborative partnerships between different groups (Cox \& Pezzullo, 2016; Pezzullo \& Cox, 2018; Dukes \& Firehock, 2001; Van Bommel et al., 2009), social learning and knowledge sharing (Ramisch, 2014), the dissemination of good agricultural practice (Ingram et al., 2016), the protection of ecosystems and natural resource management (Fisher \& Bliss, 2009; Borrini-Feyera et al., 2007), or connectivity conservation planning (Keeley et al., 2019). Most of the research that I found during the literature review is qualitative, with a preponderance of case studies describing collaborative partnerships within the framework of natural resource management solutions in specific territories.

\footnotetext{
${ }^{3}$ That is behaviour which supports environmental and nature protection, such as recycling, sustainable transport, a decrease in energy usage, and other activities (Klöckner, 2015). Pro-environmental behaviour can also include agricultural management which is beneficial for nature conservation and ecosystem services.
} 
Meierová T.: Conflicts between farmers and conservationists: the role of communication in the management of natural resources

\section{Research on communication between nature conservationists and farmers}

The research on NC communication that depicts conflicts between conservationists and farmers is very varied in terms of the theoretical background of the authors, analysis of the $\mathrm{NC}$ communication and conflicts, and details of the report on collaboration. Therefore, the literature selected for the review was divided into four groups according to the criteria mentioned below:

1. publications on pro-environmental ${ }^{4}$ communication mentioning farmers

2. studies focusing on building collaboration with farmers

3. experience of professional conservationists in $\mathrm{NC}$ communication with farmers

4. other studies dealing with an aspect of NC communication with farmers

\section{Group 1 - Publications on pro-environmental communication mentioning farmers}

Several monographs and papers deal extensively with the topic of NC communication towards specific target groups, especially the public (Cox \& Pezzullo, 2016; Pezzullo \& Cox, 2018; Peterson et al., 2016; Depoe, 2011). Their primary focus is the communication of environmental problems and potential solutions with the broader public, not specific groups such as farmers. However, case studies about conflicts involving farmers and agribusiness are also mentioned. Typically, the dispute is conducted on three levels. The first one concerns the management of a specific area. Farmers mostly demand as highly productive a use of the area as possible, whereas conservationists aim for an increase in the support for natural values, especially species richness. The second is the ownership level. Typically, the party with an economic interest, i.e. farmers who are the owner or lessor of land which lies outside protected areas with a stricter regime, have more significant legal opportunities to influence the management in comparison to conservationists. The third is the level of relationships and communication dynamics. Conflicts usually last for a prolonged period of time and frequently it is not clear from the data how the personal communication between the groups took place, who represented the groups, their level of trust, and the quality of the relationships between the groups and between the representatives.

Cox and Pezzullo's predominant focus is on indirect communication tools, environmental communication campaigns, environmental health communication, and public participation in environmental decision making. Agribusiness is mentioned in several cases as a source of water pollution that is of great concern for the public. This has generated regular conflicts between environmentalists, the public, and farmers regarding what an acceptable level of risk from the business is. Frequently, the voices of concerned citizens are not acknowledged, especially when public hearings are used to address their concerns only formally and after the decision has already been made. Similarly to the conflict cases presented by Peterson et al., (2016) and Depoe (2011), no genuine effort is put into solving the conflict using a problem-solving approach. However, a special chapter is represented by collaborative natural resource management or collaborative partnerships (see Group 2), where the parties aim to approach the conflict in a different manner than public hearings, i.e. to use long-term dialogue.

The reasons for the conflict between farmers and conservationists in the Emån basin that was described in the introduction was further investigated by Peterson et al. (2016). These authors understand communication as a process with a specific dynamic formed by a number

\footnotetext{
4 That is communication that advocates for environment and nature protection whereas environmental communication means communication concerning environment. (Klöckner, 2015).
} 
of variables, where communication can range from constructive to destructive, in which the awareness of the actors in the conflict about the principles of communication and the perception of its meaning is very important. According to the authors, the key is to establish elementary trust between the groups, with which neither party loses hope that their problem can be solved together with the other party and both at least maintain a basic level of satisfaction with the negotiation process. If the conflict between the groups lasts for a long time, the perceived satisfaction with the communication process often decreases, and consequently, the respect and trust towards the other side are further reduced. In the dispute over the flow of the Emån, both sides remained in the vicious circle of a destructive communication process. This had the result that the relationship between the farmers and conservationists was on the verge of deep distrust. To overcome the destructive process, stakeholders need to have a basic understanding of how the communication process works and how to prevent destruction.

An interesting case of conflict between farmers and conservationists took place in Klamath County, Oregon, in the USA, caused by reduced water supplies in the local stream (Depoe, 2011). The conservationists reduced irrigation to preserve populations of protected aquatic animals, triggering stormy protests by farmers dependent on irrigation from the river. What is crucial is that the farmers considered this conservationist decision a fundamental threat to their personal and economic existence and communicated it to others in a very hostile spirit. There is no description of the development prior to the conflict, but it can be inferred from this that the farmers were very likely to face a final decision of the state administration and felt that their opinion did not have any value for the state administration. This was followed by repeated violations of the law, in which the floodgates were opened unlawfully to irrigate agricultural land. The farmers felt deceived by the federal government, which was not involved in the dispute; the conflict was exacerbated by media reports. A conservationist noted that he was accustomed to receiving personal threats, but in this case, he also received them from people in uniforms. The agreement was marked by President Bush's decision to set up a special unit to ensure the maintenance of irrigation in the region, and a subsequent lawsuit against fishermen for the protection of protected species. A real solution to the conflict remained out of sight, despite various efforts at the state and federal levels. The dynamics of this communication process were, as in the previous case, destructive. In the case studies of both Depoe and Peterson et al. it was not clear if anybody was trying to reverse this development, for example, by using negotiation techniques as described by professional conservationists' manuals (see Group 3) or efforts to build collaboration with farmers (see Group 2) or other efforts.

\section{Group 2 - Studies focusing on building collaboration with farmers}

Natural resource management partnerships or what are called collaborative partnerships are initiatives of various groups with interests in the territory that seek to establish cooperation and agreement with each other (Cox \& Pezzullo, 2016). Collaborative partnership studies that attempt to address land use conflicts are available, for instance, by Van Bommel et al. (2009), (2010), Ravnborg \& Vesternbarn (2014), Conley \& Moote (2003), and Bidwell \& Ryan (2006).

Cox \& Pezzullo (2016) mention a number of case studies from the US, which - to a greater or lesser extent - tried to solve conflicts in the management of natural resources using a partnership approach. These studies mainly focused on landowners, including farmers, forestry organisations, conservationists, and other US stakeholders, and in them community-based collaboration or partnership initiatives were used to address long-term management or conflicts over nature and economic interests. The aim of collaborative 
Meierová T.: Conflicts between farmers and conservationists: the role of communication in the management of natural resources

partnerships is to establish cooperation and agreement between groups through joint negotiation under defined conditions. If agreements are reached, they often bring significant benefits to both sides; hence the interests of nature conservation are served but also the economic viability of local communities is not undermined. Five principles for the effective functioning of collaborative partnerships are defined by Cox \& Pezzullo (2016) and Pezzullo \& Cox (2018) as follows:

1. representatives of all relevant stakeholder groups take part in the negotiations;

2. the participants use a problem-solving approach or a problem-based approach. Blaming the other party is recognised as unconstructive and leads nowhere;

3. for full participation in the debate, everyone has access to the necessary information and resources. For example, public authorities provide enough comprehensible information to local people without special education in the field;

4. decisions are reached by consensus (e.g. voting by all groups involved);

5. the resulting agreements should be implemented in practice - this cannot always be ensured, but the implementation effort itself is important so that the participants feel that the whole process is leading to something.

Collaborative partnerships also have their limits. That is especially the case when natural resources are of greater than local importance (e.g. large forests important for the whole country), but representatives of local groups prevail in the negotiations, for instance, because national conservationists and other groups are late to learn about the initiative. Another limit is the risk of creating a deal that is relatively acceptable for all; thus, it is easier to achieve consensus, but it does not provide the best available solution.

The collaborative partnerships that were examined in the reports of IFRP $(2013,2017$, 2019), Van Bommel et al. (2009), and Ravenborg \& Vesternbarn (2014) tried to prevent conflict or misunderstandings about the use of natural resources, mostly water, territory, and land use between several groups defending different interests. The establishment of collaborative partnerships followed a generally similar pattern, regardless of the location.

1. Conservation groups or other stakeholder groups (e.g. forestry organisations, natural scientists, local citizens) found it crucial to protect the interests of nature, which had been previously damaged, while the farmers were concerned that if that was approved, it might have negative consequences for their management practices.

2. An attempt is made to address the problems and existing or potential conflicts by creating a platform with representatives of all major groups. The long-term objective of the platform is to reach consensus about the optimal land use of the locality.

3. In some cases, it is not initially stated that the interest of preserving ecosystems and/or natural values will automatically be one of the partnership priorities; common priorities and objectives are sought through dialogue.

4. Whether and when collaboration rules are defined depends on each case. Many of the collaborative partnerships were unlikely to know about the existence of other successful partnerships and possible rules that could help the negotiation process and the creation of agreements.

5. Whether consensus is actually achieved is influenced by a number of factors, including the degree of complexity of the environmental problem, the communication skills of the participants, previous inter-group relationships, 
motivation to communicate, or the development of negotiations (mostly satisfaction or dissatisfaction with the process).

An example of an unsuccessful collaborative partnership from Drentsche Aa in the north of the Netherlands is described by Van Bommel et al. (2009). A naturally valuable landscape with rich plant communities was damaged by pesticides and herbicides from large areas of arable land. The boundaries of the river basin did not coincide with the administrative boundaries of the regions, which complicated the involvement of all actors. The initiator of the conservation efforts was trying to have the area declared a national park. In the Netherlands, what is called 'multi-stakeholder negotiation' is a relatively standard procedure; however, the platform that was composed of representatives of different groups to negotiate land use objectives failed to agree on and implement the rules of a potential national park. The authors summarised the reasons why that happened. The actors did not feel sufficiently respected in the negotiations, were not sure that their interests and needs would be sufficiently taken into account, and blamed each other for a lack of helpfulness and willingness to compromise. The study deduces this might have been caused by the different perceptions of the problem by various groups, a lack of understanding of the interests between groups, and the subsequent misinterpretation of the behaviour of others, including decision makers.

Taking a closer look at how the Drentsche Aa initiative met the five collaborative partnership principles outlined in Cox \& Pezzullo (2016) and Pezzullo \& Cox (2018), we find that only the first principle, the participation of all relevant groups in the negotiations, was satisfactorily met. Three of the other principles were not fulfilled (consensus decision making, implementation of the results in practice) or were only fulfilled partially (problem-solving approach). Regarding the last principle, access to information resources for all, it was not possible to judge from the article how much it was or was not fulfilled.

The Idaho Forest Restoration Partnership, involving a total nine individual local partnerships in Idaho, USA, brought benefits to nature and also to groups with economic interests (IFRP 2013, 2017, 2019), although the initial situation was very similar to the previous partnership - the declaration of a national reserve led to resistance from local people. The first principle of collaborative partnerships, the participation of all stakeholders, was sufficiently fulfilled. The negotiations were attended by farmers' associations, the timber industry, several state institutions, foundations, conservation organisations, off-road drivers' associations, and indigenous peoples. The partnership was initiated by conservationists who were in a long-term conflict with farmers or the timber industry and actively assisted by politicians from the area. Importantly, the problem-solving approach was broadly applied: the organisations learned how to create constructive solutions that they expressed in a summary of recommendations. They agreed that it was necessary to respect the goals and opinions of the other groups, to be honest about the goals of their own organisation, to learn to listen and ask others for clarification if needed, and to collect information from local people as to how they would be influenced in practice by the activities of a particular organisation. They also learned how to be prepared for attacks from other organisations that did not agree with their own approach.

The principle of the fulfilment of access to information cannot be assessed on the basis of the information available from the study. Decisions were made by consensus, so another principle was applied. During the partnership, a joint organisation (Idaho Forest Restoration 
Meierová T.: Conflicts between farmers and conservationists: the role of communication in the management of natural resources

Partnership Inc. ${ }^{5}$ ) was set up to help implement the agreements that were negotiated, which were legalised by the Obama administration on the state level. Specific ways of financing nature conservation measures were also agreed. The principle of the practical application of the results was thus fulfilled, and according to the sources, the conflict resulted in reaching a more beneficial solution for the majority of the parties involved.

\section{Group 3 - The experience of professional conservationists in NC communication}

Several authors aim to gather a better understanding of the behaviour of groups that frequently do not agree with the environmentalists' interest in a specific area and the factors that contribute to this behaviour. On this basis, they seek to build more functional communication and also better relations with these groups, including farmers, who are recognised as partners in the management of natural resources. The intended recipients of the publications are local authorities and experts from professional and also non-professional conservation organisations. On the basis of their professional knowledge, Bonar (2007) and Rientjes (2000) focused on a deeper analysis of personal and institutional experience with communication that worked or did not work; they developed a set of principles for how to communicate better with people who are not too interested in the environment and would not describe themselves as environmentalists. Their work differs in many respects, but both present a set of findings affecting the quality of several communication episodes between environmentalists and farmers and offer recommendations for establishing effective communication and preventing misunderstandings.

Developing dialogue with farmers on nature conservation is dealt with in a part of the manual produced by Rientjes (2000), which builds on knowledge from the work of the non-profit sector in Britain, the Netherlands, and Canada. The author points out that as conservationists are mostly educated in nature conservation and ecology, they therefore understand the natural system in a certain way. Subsequently, they presume that the communication partner (although with a different background) will understand the problem in a similar way and they will know what a conservationist is talking about. Unfortunately, this is frequently not so. This can be well illustrated by the case of the implementation of the Nature Policy Plan in the Netherlands, where the public administration has traditionally sought good communication with stakeholders. The plan was the result of the work of NGOs that pushed the government to promote greater conservation in the country. The plan offered farmers financial compensation for more environmentally friendly farming (e.g. fertilisation, mowing) and the opportunity to sell land under the Ecological Main Structure ${ }^{6}$. All the measures were voluntary. The problem was that farmers did not participate in the programme at all, which was surprising given the long preparation and consultation process. A study to explain the reasons for the failure showed that farmers did not understand why they should take any measures at all. In their view, nature is everything that breathes, grows, or blooms; they considered nature to exist, despite or even with the help of agricultural practices. They were unaware of concepts such as the functioning of ecosystems, the importance of corridors for wildlife, or biodiversity; which Rientjes (2000: 36) characterised as: "Their nature is doing fine!" This story had an interesting ending. After some time, farmers found that the neighbourhood perceives them as a group that pollutes the environment and destroys nature. Their primary disinterest in communication with the government and other organisations

\footnotetext{
${ }^{5}$ IFRP Incorporated means an incorporated association that is separate from the members that form it, who are not accountable for the actions of the company.

${ }^{6}$ A form of ecological network, the basic idea of which is similar to the Territorial System of Ecological Stability in the Czech Republic.
} 
gradually changed; they started to be willing to return to the negotiation process. Their motivation, in this case, could be the pressure of social norms (not to be perceived as a polluter) and their need to be a respected member of society.

In this context, it can be added that the suspicion and unwillingness of farmers towards policy measures of various kinds may be due, inter alia, to the fact that farmers feel permanently constrained with regard to what they can and cannot do on their land, but at the same time they have to survive economically, which can be very difficult, although for centuries farming has been a cornerstone of the economies of European states (Guerrier 2006; Gronewold et al., 2012). If this issue is not sufficiently addressed in the negotiations, there is a risk that cooperation will collapse. Rientjes adds further communication difficulties. One is the mismatch of the intentions and opinions of various conservationists, as the lack of a common opinion can create distrust in farmers and damage the negotiation process.

Unlike Rientjes, Bonar (2007) focuses more on the communication and skills of a conservationist who wants to resolve conflicts with various stakeholders; it is indeed the skills of the individual that he considers to be the key to success. In his work he uses the principles of persuasion by Cialdini (1993) and the rules of effective bargaining according to Fisher et. al. (1991), who advise disarming criticism by agreeing with a part of the critic's argument, an empathetic statement that demonstrates an understanding of the critic's situation, and using compliments instead of criticism. From his personal experience, Bonar considers these principles useful for resolving conflicts between environmentalists and other groups when properly applied. On the other hand, similarly to Rientjes, he does not present his own long-term scientific research on communication in conflict situations; his conclusions stem from long-term observation and professional experience.

\section{Group 4 - Studies dealing with an aspect of communicating nature conservation with farmers}

A significant part of the papers suggested how to improve communication with farmers studied the impacts of agri-environmental measures, natural resource management, and other issues related to farmers and nature conservation. Although in most cases only a few relevant sources concerning communication and conflict description were mentioned, they propose how communication on conflict solution might be handled according to their empirical findings and the data can provide insights into what can contribute to better direct communication for conflict resolution.

A case study by Fisher \& Bliss (2009) investigated the perception of the protection of oaks by conservationists and landowners in Oregon, where the oaks are located. Nature conservation measures were intended to help resolve an inexplicit conflict between the conservation of a specific habitat and the pursuit of farming and real estate development. In addition to the recommendation to provide farmers with information that can be used in practice, the authors mention different approaches to communication by various conservationists. The conservationists felt the need for better communication and mentioned two ways to achieve it. Some considered it more practical first to negotiate conservation goals for the oaks with other groups, i.e. landowners and real estate agents, without the participation of farmers and then the present results to them. This could theoretically disrupt good negotiation according to the principles of collaborative partnerships, where the agreement is negotiated consensually with the participation of all parties. On the other hand, having a "pre-arranged position" for more conservation groups may be beneficial because of the greater clarity of the requirement or information that conservationists want to communicate to farmers (Rientjes, 2000). Another suggestion for improving communication 
Meierová T.: Conflicts between farmers and conservationists: the role of communication in the management of natural resources

was to reduce the environmentalists' own prejudices against other groups. As already mentioned, prejudices generate "us versus them" thinking, images of an enemy, and subsequent conflict between groups. It seems to be more useful not to be affected by prejudices, to be responsive, and to adapt the conversation to reflect the issues and interests that are common to all participants.

Also, finding a mechanism that provides financial support to the long-term interests and goals of the participating groups may be the key to success (Keeley et al., 2019; Rientjes, 2000; Bonar, 2007). For instance, in order to produce Natural Community Conservation Plans in California, stakeholder groups such as developers, farmers, and state authorities cooperate to produce and financially secure a win-win solution for all the parties affected (Keeley et al., 2019). The plans include detailed implementation steps that ensure the proper implementation of conservation measures, data collection, and monitoring, including sufficient staff time to oversee the activities, which require well-designed financing mechanisms.

The question of how the state administration can contribute to strengthening the pro-environmental behaviour of farmers when it is necessary to communicate with as many farmers as possible has been explored by several sources (Dwyer et al., 2007; Garforth, 2010). Communication needs to be timed at the right moment when deciding on the choice of the appropriate behavioural alternative, which is consistent with Klöckner's recommendation (2015: 94). Among the best measures to address farmers, Dwyer et al. (2007) suggested the farming press, personal advice from advisors trusted by farmers, and also discussion groups. A good facilitator with sufficient knowledge of farmers' problems, needs, and goals may be crucial. On the other hand, farmers' response to computer-based communication is generally low (Dwyer et al., 2007; Rientjes, 2000) and expectations that social media would be a suitable tool to persuade farmers to adopt more environmental practices were exaggerated. Neither did unsolicited advice from organisations that are not trusted by farmers seem to be effective. Moreover, it is crucial to realise that farmers' behaviour largely depends on contextual factors, and it is not realistic to expect that it can be influenced only by communication.

For a person or organisation that wants to communicate efficiently with farmers, it is important to understand that the essence of reporting is socially constructed, and therefore we first need to know the farmer whom we wish to approach and to have an understanding of farming styles and industry conditions (Dwyer et al., 2007; Garforth, 2010). When cooperation and trust are established, both conservationists and farmers can continue to develop solutions together and, preferably, stay in long-term contact. Responding to the intentions and needs of both parties is essential. If an individual or organisation wants to provide farmers with advice, it should meet the needs of specific groups of farmers, possibly according to the typology of farms or farmers ${ }^{7}$. The farmers who were included in Dwyer's sample represented a total of five nature conservation initiatives (waste, soil, water, and their combinations). They complained, among other things, of too much information that they had to sort and evaluate, although they did not have the capacity to do so. However, the information aimed at farmers may receive more attention if it offers a financial advantage, is aimed at a beneficial solution to the farmer's problem, or targets other stronger concerns and beliefs. Some of these findings broadly correspond to the principles of persuasion by Cialdini (1993).

\footnotetext{
${ }^{7}$ Typologies were designed, e.g. by Dwyer et al. (2007) and Garforth (2010).
} 
Clearly, farmers want communication and advice from conservationists that are convenient and useful to them and have high credibility in their opinion and messages that are imaginative, offer new solutions to their problems, and are legitimate in that what is recommended is in accordance with the law (Ingram et al., 20016; Winter, 1996). Mistrust between environmental professionals and farmers frequently hinders the cooperation farmers may not consider it necessary to listen to the other party because they do not believe their recommendations will have any benefits. If a farmer has already agreed to be advised by a conservationist and tries to apply his advice, it is necessary to focus strongly on the high quality of the recommendations and on monitoring whether they are used in practice (Winter, 1996).

The general principles of collaboration and communication for conflict resolution identified in the literature are summarised below. Only the principles that appear to be the most relevant from the literature that was researched, which are mentioned by several authors, and/or were applied in the case studies to improve collaboration and communication are listed.The principles were further used as an assessment framework in the case study.

1. Representatives of all relevant stakeholder groups are involved (Cox \& Pezzullo, 2016; Pezzullo \& Cox, 2018).

2. Participants use a problem-solving approach or a problem-based approach (Cox \& Pezzullo, 2016, Pezzullo \& Cox, 2018).

3. Everyone has access to the necessary information and resources (Cox \& Pezzullo, 2016, Pezzullo \& Cox, 2018).

4. Decisions are reached by consensus (Cox \& Pezzullo, 2016, Pezzullo \& Cox, 2018).

5. The resulting agreements should be implemented in practice (Cox \& Pezzullo, 2016, Pezzullo \& Cox, 2018).

6. The level of constructiveness of the dialogue is sufficiently high (Peterson et al., 2016).

7. The opinions of the public and other groups are important to farmers (Rientjes, 2000).

8. A sufficient level of trust between the parties is established (Dwyer et al., 2007, Garforth, 2010).

9. Special communication techniques to advocate on behalf of the environment help to resolve complicated situations (Bonar, 2007).

10. Suitable financing that supports the implementation of the agreements and involvement of actors is employed (Keeley et al., 2019; Rientjes, 2000; Bonar, 2007).

11. Efforts to reduce existing prejudices between the groups are made (Rientjes, 2000; Fisher \& Bliss, 2009).

12. Efforts to understand farming styles, industry conditions, and other aspects of the context are made (Dwyer et al., 2007; Winter, 1996; Ingram et al., 2016).

13. Farmers are not approached with unsolicited advice (Winter, 1996; Ingram et al., 2016).

\section{CASE STUDY: SPECIFIC COLLABORATIVE INITIATIVE BETWEEN A FARMER AND A SMALL MUNICIPALITY IN SOUTH MORAVIA}

To the best of my knowledge, there has hitherto been no scientific case study available about potential collaborative partnerships between farmers, conservationists, and other stakeholders in the Czech Republic that focus on improving nature management. A specific 
Meierová T.: Conflicts between farmers and conservationists: the role of communication in the management of natural resources

collaboration initiative has been developed between a farmer, a municipality, and other local people in a village in South Moravia with 427 inhabitants, which has faced the long-term problem of intensive agricultural production, a low amount of green infrastructure, and subsequent impacts such as increased erosion, problems with biodiversity, and a decline in the condition and value of the landscape.

In 2015, a young farmer who had newly moved into the village began to purchase land to establish a farm in the surrounding parishes and started to grow alternative crops. It should be highlighted that the farmer has a degree in conservation and at the same time substantial skills with growing crops such as fruit trees, vegetables, and mushrooms, which can be considered a unique background. He has shown a strong desire to contribute to solving the problems in the countryside, especially a lack of habitats for species such as birds, insects, and plants that traditionally co-existed with the agricultural crops in the past. Since his childhood, he has also perceived erosion and a deterioration in the quality of the soil, including its retention properties, and has been aspiring to address those issues as well. The farmer claims that at the local level, these problems and also a long-term decrease in biodiversity are the results of the unsustainable practices of the large agribusiness companies that manage the majority of the land in the area. In his opinion, large companies are not willing to change the way they cultivate the land for a variety of economic, administrative, and organisational reasons. Therefore, he decided to take action himself. Although he assumed the bigger agribusinesses in the area would not appreciate it, he started to make long-term strategic land purchases: gradually, he managed to buy plots of land scattered around the parish and also the neighbouring land registry area, including a meadow with conservation potential. On the farmland, alfalfa was usually planted as a preparation crop, followed by fruit trees with species-rich grassland. Apart from these types of land use, the farmland also includes grassland strips, fallow land, and nesting sites for protected birds. As a result, several rare and protected bird species have taken refuge on his plots.

The local authorities of the village have aimed to improve the environmental conditions in the countryside for several years. Therefore, a long-term interest that is shared by both the farmer and the municipality can be seen as a key to cooperation. The municipality, several local people from the village with various professions interested in improving natural values in the area, and the farmer created the first joint project - an avenue of fruit trees for which the farmer-conservationist designed the planting scheme and selected the varieties of trees used. In the unofficial partnership, the farmer's role thus included the positions of both a farmer and a conservationist. The process of project development was closer to a discussion than a negotiation as described in the case studies of collaborations from the Netherlands and the US (see Group 2). However, this was not the case of the second project that followed, a significantly larger one. On the strips of land owned by the municipality with an area of approx. 10 hectares but currently rented by large agricultural businesses new green infrastructure (mostly permanent grassland with shrubs and trees dividing large fields) was designed by the farmer, with the potential to improve the ecosystem services in the area but on the other hand to complicate the current practices of the larger farmers and also the work of the mayor of the village, who aimed to stay on friendly terms with the large agricultural companies.

The unofficial partnership was assessed according to the principles summarised in the literature review. The first principle, according to Cox \& Pezzullo (2016), that all relevant stakeholder groups participate was fulfilled only partially. The majority of stakeholder groups were involved, that is the municipality, the smaller farmer and at the same time conservationist, and several inhabitants of the village. However, the large agricultural 
businesses managing the majority of the land in the parish were not fully included; they were only informed about the projects.

During the preparation of the second project bigger businesses approached the mayor of the municipality and tried to alter their decision making so that the division of the fields would not be permanent. They preferred to establish strips of grassland that could be turned back into fields easily instead of permanent grassland with trees and bushes. This generated a smaller disagreement between the smaller farmer and the mayor over the usage of the municipality plots and threatened the cooperation in the partnership. The conflict was solved thanks to the efforts of the deputy mayor, who intervened and persuaded the mayor to reject proposals of the agribusiness. The power distribution, in this case, enabled the smaller farmer and municipality to carry on with the nature management projects regardless of the opinions, preferences, and interests of bigger businesses as the land in question is owned by the municipality. However, this can be seen as a limitation of this collaborative partnership: bigger farmers find dividing the land into smaller plots rather unfavourable as it slows down crop management and thus a conflict of interests exists outside the partnership that has not been addressed by dialogue or negotiation. Also, the businesses continue to farm as usual on the rest of their land, unaffected by the initiative. Therefore, the environmental benefits are currently limited to the land owned by the municipality and the smaller farmer.

The second principle, that participants use a problem-solving approach, as blaming others does not help, was applied thoroughly. According to the information gathered, from the beginning, there was a clear commonly perceived problem of lower ecosystem services by the farmer, the municipality, and several local inhabitants. There was no need to blame the groups that were directly involved. Nevertheless, it is likely that bigger businesses may blame the partnership for not including them in the decision making, and the management of their plots is now more complicated. This may generate difficulties if their consent is needed in the future. The third principle, that everyone has access to the necessary information, was applied in the partnership. Both the smaller farmer and the municipality had enough information to develop both projects together. Detailed information for the public is available on the farm website with a structured presentation of its goals, products, and projects accompanied by photographs, which serves as an information channel for the general public; however, it is not possible to say what percentage of the inhabitants of the village were directly informed about the second project to be prepared. The fourth principle, concerning decision making in the partnership, was also fulfilled. The common goals of the smaller farmer, the municipality, and several local citizens enabled smooth discussions and relatively easy agreements on the steps that were taken to prepare both projects supporting biodiversity. No significant disagreements regarding the projects were monitored.

Next, the principle of collaboration promoted by Cox \& Pezzullo (2016), that the resulting agreements should be implemented in practice, has clearly been fulfilled as the first project has already been carried out. The projects of the smaller farm have led to a documented increase in the occurrence of rare bird species, insects, and other animals, some decrease in erosion, and a likely increase in water retention, although it is not possible to estimate the size of the effect as measurements are difficult to make. The second, larger project is waiting for the approval of financial support and should be implemented in the future.

The level of constructiveness of the dialogue (Peterson et al., 2016) within the partnership was high enough to enable the creation of not only the first smaller-scale project but also the second, bigger project. Nevertheless, as noted previously, the dialogue with large agricultural companies remained limited, and factually they were not included in the partnership. From the data, it is not possible to assess the constructiveness of the dialogue outside the partnership. Next, the principle concerning how farmers think the public perceives them and 
Meierová T.: Conflicts between farmers and conservationists: the role of communication in the management of natural resources

if those opinions are considered important (Rientjes, 2000) was assessed. During the last decade, the Czech public has become increasingly concerned about pollution, the negative impacts of farming on biodiversity, and other ecosystem services. In this particular case, the small farmer is building his business reputation as a citizen who is eager to apply only environmentally friendly practices and is farming sustainably to provide benefits both to the environment and society. Public opinion is important to him as it affects the number of supporters of his projects and buyers of his products. However, the main motivation of the small farmer to be involved in the partnership was not how the public perceives him, but his goal of improving environmental conditions in the area. The level of trust between the groups, which is a principle mentioned by Dwyer et al. (2007) and Garforth (2010), has been sufficient enough to carry out the preparation of both projects. The representatives of the village knew the farmer for a longer period of time and saw his previous work in the countryside, which convinced them the farmer had sufficient skills and trustworthiness to prepare the green infrastructure project covering a significant part of the municipality's plots. Similarly, the farmer trusted that the municipality's intention to create landscape elements on its land was genuine. The mutual trust seems to be slightly affected by the fact that when a large agribusiness approached the municipality with an offer to create only temporary grassland, which would exclude the smaller farmer and his ideas from the project, their offer was not accepted by the mayor as a result of the efforts of the deputy mayor, who convinced him not to compromise. This episode might have had an impact on the presence of prejudices between the farmer and the staff members of the municipality, which can be seen as another principle affecting dialogue and cooperation (Rientjes, 2000; Fisher \& Bliss, 2009). The evidence suggests that the groups involved in the partnership had not been prejudiced against each other at the beginning of the cooperation. However, after the mayor showed an inclination to compromise with the agribusiness, the farmer seemed to become more cautious about his future actions and started to consider the mayor to be less responsible and committed to their common project.

Special communication techniques to facilitate dialogue (Bonar, 2007), such as using empathy statements, using compliments, or agreeing with criticism from other group have not been used, according to the data gathered. Neither a professional facilitator nor a mediator was involved in the development of the partnership, as the aims of the small farmer and the municipality were very similar. Also, neither the farmer nor municipality staff were skilled in negotiation or facilitation; the broker function was taken by partially by the farmer himself and partially by the deputy mayor of the village, who was convinced of the benefits of the cooperation. Another principle that is applicable for this case study is ensuring suitable financing that supports the implementation of the agreements and the involvement of the actors (Keeley et al., 2019; Rientjes, 2000). The finances necessary for implementation of the first, smaller project were secured by the municipality, farmer himself and his supporters from their own sources as this did not require any funding application and administration. The second, larger project required more substantial financing therefore an application to a suitable grant scheme had been submitted by the municipality and was waiting for the approval.

The last two principles, understanding farming styles, industry conditions and other aspects of the context, and not approaching farmers with unsolicited advice seemed not to be of high significance to this particular partnership. Before the first project, the representatives of the municipality were approached by the small farmer himself and municipality did not attempt to give him any advice concerning his practices or change his farming styles. 
The practical results of the collaborative partnership are significant and can bring much-needed green infrastructure to the area, with related environmental benefits. However, as stated previously, the dissemination of the environmentally friendly practice to other agribusinesses in the area and creating potential cooperation with them in the future may be problematic. Another limit is the area of land which the partnership can directly influence, which is several hectares. If the partnership included at least one large business, positive environmental effects could affect not only a 60-ha area but several hundred hectares.

The case study can be seen as specific thanks to the fact that the farmer has at the same time a deep interest in conservation. Despite this, the results that he, the leaders of the village, and the local people involved managed to reach are in some aspects similar to a more standard collaborative partnership, which brings improved conservation goals to the region in question.

\section{DISCUSSION AND CONCLUSIONS}

Although the literature review showed that literature on conflicts related to forests and their usage predominates, a certain amount of material dealing with $\mathrm{NC}$ communication with farmers in conflict situations is also available. The authors come from various disciplines and differ in their general approach to the issue of communication and conflict resolution with farmers; nevertheless, some similar principles that contribute to better communication and collaboration between the groups can be traced in their findings. Most authors make a number of recommendations for improving communication between conservationists and farmers. Environmentalists have many options which they can use in order to create greater trust in farmers when it comes to face-to-face communication (Rientjes, 2000; Bonar, 2007; Dwyer et al., 2006). Communication and negotiation techniques can be useful if there is sufficient knowledge of the whole process, including the fundamentals of communication dynamics, negotiation principles, such as openness to new solutions, and that part of the farmers' behaviour is dependent on external factors, and it is not realistic to expect it to change too rapidly. In total 13 principles that appear to be the most relevant from the literature that was researched, which are mentioned by several authors and/or were applied in the case studies to improve collaboration and communication, were identified. Nevertheless, it can be argued that more recommendations could be derived from the review, depending on the understanding of what makes the communication between environmentalists and farmers successful. The principles of the "problem-solving approach" are somewhat consistent with the characteristics of the constructive communication process, as outlined by Peterson et al. (2016). In both cases, it is emphasised that blaming other stakeholder groups and ignorance of the dynamics of the communication process can lead to an escalation of mutual intolerance. Several case studies document aspects of efforts to solve conflicts that met with varying degrees of success; however, the only examples of notable concrete conflict resolutions were found in collaborative partnership studies (Group 2 from the literature review), where more principles of building trust between groups and long-term problem solving were applied than in the cases listed in the studies in Groups 1, 3, and 4, which usually mention one or two general principles.

It is important to note that conflict resolution using standard methods of $\mathrm{NC}$ communication (e.g. regular educational leaflets, films, etc.) seems not to be realistic. Overcoming prejudice through negotiation in a long-term partnership seems more appropriate than using information materials; building at least basic respect between conservationists and farmers and finding common goals is of the highest importance. The 
Meierová T.: Conflicts between farmers and conservationists: the role of communication in the management of natural resources

studies from the literature review do not pay much attention to the question of how to deal with unresolved past events and related emotions that can contribute to present conflicts.

In the case of the collaborative partnership, the results of the Czech case study point to the need to fulfil most of the five principles identified by Cox \& Pezzullo $(2016,2018)$ and also several other principles in order to start a sufficiently high-quality dialogue and to make the partnership work. If some of the principles are not fulfilled, there seems to be a greater risk that the problem on which the partnership is working will not be resolved. Clearly, the results of the case study have several limits. The collaborative partnership and conflict with bigger agribusinesses were described on the basis of the data from the small farmer and the viewpoints of larger businesses are missing, as interviews with large farms and the municipality were not carried out as a result of the research design. However, the concerns of the large farms and their perceptions of the environmental problems, conflicts, and cooperation with other parties are not the aim of the case study, which was to find and describe an example of a Czech collaborative partnership. Several specific situational factors clearly affected the process of the development of the partnership. The farmer has a very specific background, a long-term interest in nature protection, and an academic degree in ecology. No representative research on the education of farmers in the Czech Republic is available; however, during the past five years, I have come across relatively few South Moravian farmers with an interest in conservation and practically no one with an ecology degree. The partnership was supported by the majority of the village representatives and especially the mayor of the village. If the municipality is not certain about participation in the partnership, cooperation may not be sustained in the long term. The partnership also has sufficient skills to secure finances for the implementation of the projects thanks to the unpaid work of the small farmer and village representatives. The replicability of the partnership elsewhere in Moravia may be limited as a result of the above-mentioned context, particularly the educational background of the farmer.

More research on conflict resolution and potential collaboration between agricultural and nature conservation interests in the Czech Republic could be helpful as it may lead to increased understanding, better dialogue, and solutions that would be more feasible for both environmentalists and farmers.

\section{ACKNOWLEDGEMENT}

The preparation of this article was supported by the Specific Research Project of Masaryk University No. MUNI/A/1158/2018.

\section{REFERENCES}

Bednárová, L. (2016). Agrarian Analyst Havel: Society Has to Change Its Attitude Towards Landscape, Retrieved July 3, 2016, from http://www.euractiv.cz/rozvoj-venkovav-reformovane-szp/interview/agrarni-analytik-havel-spolecnost-se-musi-zacit-chovat-ke-kr ajine-lepe-013187.

Bonar, Scott A. (2007). The Conservation Professional's Guide to Working with People. Washington, DC: Island Press.

Borrini-Feyera, G. and Deutsche Gesellschaft für Technische Zusammenarbeit (2007). Co-Management of Natural Resources. Organising, Negotiating and Learning-by-Doing. Heidelberg: Kasparek, 2007. 
Cialdini, R. B. (1993). Influence: The Psychology of Persuasion. Rev. ed. New York: Morrow.

Conley, A. and M. Moote (2003). Evaluating Collaborative Natural Resource Management. Society \& Natural Resources 16 (2003): 371-86. https://doi.org/10.1080/089419203901 90032 .

Cox, J. R., and Ph. C. Pezzullo (2016). Environmental Communication and the Public Sphere. 4th edition. Los Angeles: SAGE.

Daňková, A. (2009). Nature Conservation in the Microregion Peace Monument Through the Eyes of Mayors. Bachelor's thesis, Brno: Masaryk University, Faculty of Social Sciences. https://is.muni.cz/th/jfuhx/.

Depoe, S. P. (2011). The Environmental Communication Yearbook. Volume 3, 2011. http://search.ebscohost.com/login.aspx?direct=true \&scope=site $\& d b=n l e b k \& d b=n l a b k \& A N$ $=704312$.

Dukes, E. F., Firehock, K. (2001). Collaboration: A Guide for Environmental Advocates. Charlottesville, Virginia, University of Virginia, The Wilderness Society and National Audubon Society, 2001.

Dwyer, J., Mills J., Ingram J., Burton R., and K.L. Blackstock (2007). Understanding and Influencing Positive Behaviour Change in Farmers and Land Managers - a Project for Defra. Retrieved November 30, 2007, from http://sciencesearch.defra. gov.uk/Default.aspx? Menu=Menu\&Module=More $\&$ Location=None $\&$ Completed $=0 \&$ Proje ctID $=14518$

Ekotoxa (2018). Územní studie krajiny SO ORP Veselí nad Moravou. Retrieved November 3, 2018, from https://veseli-nad-moravou.cz/uzemni-studie-krajiny-so-orp-veseli-nadmoravou/ds-44311/archiv=2\&p1=77539

Faberová, T. (2016). Adaptation on Impacts of Climate Change in the South Moravia Region - Barriers in Agriculture. In Černušáková L. Rural Landscape 2016. Proceedings of the 14th International Interdisciplinary Conference held on 19 - 22 May 2016 in Hostětín, White Carpathians. Kostelec nad Černými lesy: Lesnická práce, s.r.o., (2016): 141 - 146. ISBN 978-80-7458-083-3.

Fischer, A. P., and J. C. Bliss (2009). Framing Conservation on Private Lands: Conserving Oak in Oregon's Willamette Valley. Society \& Natural Resources 22, no. 10 (19, 2009): 884-900. doi:10.1080/08941920802314926.

Fisher, R., Ury W., and B. Patton (1991). Getting to Yes: Negotiating Agreement without Giving in. 2nd ed. / by Fisher, Ury, and Patton. Boston: Houghton Mifflin, 1991.

Garforth, Ch. (2010). Motivating Farmers: Insight from Social Psychology, University of Reading, 2010. http://nmconline.org/articles/garforth2010.pdf.

Gronewold, K. L., Burnett, A. and M. Meister (2012). Farmers' Cynicism Toward Nature and Distrust of the Government: Where Does That Leave Conservation Buffer Programs? Applied Environmental Education \& Communication 11, no. 1 (January 2012): 18-24. doi:10.1080/1533015X.2012.728061.

Guerrier, S. (2006). Farmers, Farming \& Change: A Social Psychological Analysis. London School of Economics and Political Science University of London, 2006. http://etheses.lse.ac.uk/1972/1/U237410.pdf.

Hanák, P. (2017). How the Czech State Punishes Those That Damage Agricultural Land. Soil Protection. March 27, 2017. http://www.ochrana-pudy.cz/hrozby-pro-pudu/jak-ceskystat-tresta-ty-co-poskozuji-zemedelskou-pudu/2017/03/27/. 
Meierová T.: Conflicts between farmers and conservationists: the role of communication in the management of natural resources

Henle, K., Alard D., Clitherow J., Cobb P., Firbank L., Kull T., McCracken D. (2008). Identifying and Managing the Conflicts between Agriculture and Biodiversity Conservation in Europe-A Review. Agriculture, Ecosystems \& Environment 124, no. 1-2 (March 2008): 60-71. doi:10.1016/j.agee.2007.09.005.

IFRP (2017). Collaborative Forest Restoration in Idaho Assessment and Recommendations. Idaho Forest Restoration Partnership, 2017. http://0104.nccdn.net/1_5/155/348/177/ Collaborative-Forest-Restoration-in-Idaho---October-2017-Rev-2.pdf\#RDAM17673402.

IFRP (2013). Collaborative Forests Restoration in Idaho. Report. Idaho Forest Restoration Partnership, 2013. http://0104.nccdn.net/1_5/08e/340/2aa/IFRP-Report-onCollaborative-Forest-Restoration.pdf\#RDAM14662068.

IFRP (2019). Idaho Forest Restoration Partnership Workshop on Shared Stewardship. Discussion, Conclusions and Recommendations." IFRP, April 30-May 1, 2019 Boise, Idaho. http://0104.nccdn.net/1_5/3c9/2bb/120/IFRP-Shared-Stewardship-Report-6-25-19.PDF\#R DAM17997813.

Ingram, J., Mills J., Dibari C., Ferrise R., Bahadur Ghaley B., Grønbech Hansen J., Iglesias A. (2016). Communicating Soil Carbon Science to Farmers: Incorporating Credibility, Salience and Legitimacy." Journal of Rural Studies 48 (December 2016): 115-28. doi:10.1016/j.jrurstud.2016.10.005.

Jacobson, S. K. (2009). Communication Skills for Conservation Professionals. Washington, DC: Island Press, 2009. http://site.ebrary.com/id/10554556.

Kächele, H, and Dabbert S. (2002). An Economic Approach for a Better Understanding of Conflicts between Farmers and Nature Conservationists - an Application of the Decision Support System MODAM to the Lower Odra Valley National Park." Agricultural Systems 74, no. 2 (November 2002): 241-55. doi:10.1016/S0308-521X(01)00087-7.

Keeley, A. T H, Beier P., Creech T., Jones K., Jongman HG R., Stonecipher G., and G. M Tabor (2019). Thirty Years of Connectivity Conservation Planning: An Assessment of Factors Influencing Plan Implementation'. Environmental Research Letters 14, no. 10 (30 September 2019): 103001. https://doi.org/10.1088/1748-9326/ab3234.

Klöckner, Ch. A. (2015). The Psychology of Pro-Environmental Communication. London: Palgrave Macmillan UK, 2015. doi:10.1057/9781137348326.

Leeuwis, C. (2000). Reconceptualizing Participation for Sustainable Rural Development: Towards a Negotiation Approach. Development and Change 31, no. 5 (November 2000): 931-59. doi:10.1111/1467-7660.00184.

McEachern, Ch. (1992). Farmers and Conservation: Conflict and Accommodation in Farming Politics. Journal of Rural Studies 8, no. 2 (April 1992): 159-71. doi:10.1016/0743-0167(92)90074-G.

Peterson, T. R., ed. (2016). Environmental Communication and Community: Constructive and Destructive Dynamics of Social Transformation. Routledge Studies in Environmental Communications and Media. London; New York, NY: Routledge, 2016.

Pezzullo, Ph. C., and J. R. Cox (2018). Environmental Communication and the Public Sphere. Fifth Edition. Los Angeles, California: SAGE, 2018.

Ramisch, J. J. (2014). They Don't Know What They Are Talking About: Learning from the Dissonances in Dialogue about Soil Fertility Knowledge and Experimental Practice in Western Kenya." Geoforum 55 (August 2014): 120-32. doi:10.1016/j.geoforum. 2014.05.009. 
Ravnborg, H. M., and O. Westermann (2002). Understanding Interdependencies: Stakeholder Identification and Negotiation for Collective Natural Resource Management. Agricultural Systems 73, no. 1 (July 2002): 41-56. doi:10.1016/S0308-521X(01)00099-3.

Rientjes, S., ed. (2000). Communicating Nature Conservation: A Manual on Using Communication in Support of Nature Conservation Policy and Action. Technical Report Series. Tilburg: European Centre for Nature Conservation, 2000.

Saltiel, I. M. (1998). Defining Collaborative Partnerships. New Directions for Adult and Continuing Education 1998, no. 79 (1998): 5-11. https://doi.org/10.1002/ace.7901.

Šálek, M., Hula V., Kipson M., Daňková R., Niedobová J. and A. Gamero (2018). Bringing Diversity Back to Agriculture: Smaller Fields and Non-Crop Elements Enhance Biodiversity in Intensively Managed Arable Farmlands'. Ecological Indicators 90 (July 2018): 65-73. https://doi.org/10.1016/j.ecolind.2018.03.001.

Štěpán, M. (2017). Suistainability of the Jemnice-Landscape Area. Master's thesis, Brno: Masaryk University, Faculty of Science. https://theses.cz/id/m3kd86/?isshlret=Marek\% 3B\%C5\%A0t\%C4\%9Bp\%C3\%A1n\%3B;zpet=\%2Fvyhledavani\%2F\%3Fsearch\%3D\%C5 $\% \mathrm{~A} 1 \mathrm{t} \% \mathrm{C} 4 \% 9 \mathrm{Bp} \% \mathrm{C} 3 \% \mathrm{~A} 1 \mathrm{n} \% 20 \mathrm{marek} \% 26$ start\%3D1.

Van Bommel, S., Röling N., Aarts N., and E. Turnhout (2009). Social Learning for Solving Complex Problems: A Promising Solution or Wishful Thinking? A Case Study of Multi-Actor Negotiation for the Integrated Management and Sustainable Use of the Drentsche Aa Area in the Netherlands." Environmental Policy and Governance 19, no. 6 (November 2009): 400-412. doi:10.1002/eet.526.

Winter, M. (1996). Landwise or Land Foolish? Free Conservation Advice for Farmers in the Wider English Countryside." Landscape Research 21, no. 3 (November 1996): 243-63. doi:10.1080/01426399608706491 